\title{
Weak Labour, Strong Interests: Polish Trade Unions and the Integration of EU Energy and Service Markets*
}

\author{
MAGDALENA BERNACIAK ${ }^{1}$ and ALEKSANDRA LIS ${ }^{2}$ \\ ${ }^{1}$ European Trade Union Institute (ETUI). ${ }^{2}$ Adam Mickiewicz University in Poznań
}

\begin{abstract}
This paper examines the motives behind the EU-level activism of CEE trade unions, which are commonly regarded as weak actors. To this end, it studies lobbying and protest actions staged by Polish labour organizations in relation to proposals for the EU Emission Trading Scheme Directive and the EU Services Directive. The analysis confirms the salience of interest-based accounts of supranational union action, but it also shows that labour interests are contextspecific, influenced by economic conditions and regulatory changes in particular market segments. In this regard, priority given by the unions to job preservation or the improvement of social standards has important implications for their positions; it also determines the selection of their allies at national and transnational levels.
\end{abstract}

\footnotetext{
Keywords: trade unions; central-eastern Europe; Internal Market; emission trading; service liberalization

Magdalena Bernaciak, Aleksandra Lis: Weak Labour, Strong Interests: Polish Trade Unions and the Integration of EU Energy and Service Markets. In: Journal of Common Market Studies 55(3), 432-448 (2017). Wiley-Blackwell

The original publication is available at the publisher's web site: https://doi.org/10.1111/jcms.12506

Introduction

The MPIfG Journal Articles series features articles by MPIfG researchers and visiting scholars published in peer-reviewed journals. Max Planck Institute for the Study of Societies (MPIfG) Cologne | www.mpifg.de
}

The EU integration process involved a shift of law-making competences from national to supranational authorities. This, in turn, impacted on the strategies of organized actors: with the growing number of regulatory tasks performed at the supranational level, EU institutions became targets of these actors' lobbying and collective action, which they often performed in co-operation with their counterparts from other countries. As demonstrated by Beyer (2002), such EU-level activism was largely the domain of organizations that were strong in their domestic arenas and possessed the resources necessary to extend their activities beyond state boundaries.

Judged on Beyer's account, central and eastern European (CEE) trade unions are unlikely candidates for supranational advocacy and mobilization. Between 1992 and 2012, they lost 77 per cent of their members as a result of transition-related restructuring and their own strategic choices (Visser, 2015); they have also been highly fragmented and dependent on political parties (Avdagić, 2004). With the exception of Slovenia, organized labour in CEE had a limited impact on socio-economic policy-making processes, and formal social pacts in the region remained rare (Bohle and Greskovits, 2010). In view of these characteristics, labour organizations from new EU Member States could be considered a critical case for interest group involvement at EU level: their weakness would

\footnotetext{
*This work was partially supported by student research grants offered by Central European University, and by the Hans Böckler Foundation grant 'The Europeanization of Trade Unions in the Countries of the Eastern Enlargement. Perspectives for Interest Representation by Trade Unions and for Trade Union Solidarity within the EU, 2012-2014'. The authors would also like to thank Svetoslav Salkin for helpful discussions on the paper's argument.
} 
appear to make them incapable of effective interest representation and collective action 'in Brussels'.

Contrary to this pessimistic outlook, however, there is evidence of CEE trade union involvement beyond state boundaries. Liaising with their colleagues from other countries, they have participated in information exchange, joint negotiations with company management and cross-border protests (Greer and Hauptmeier, 2012). Having become aware of the EU's growing decision-making powers, they have also sought to make their voice heard in European debates (Landgraf and Pleines, 2015). Yet the literature is inconclusive with regard to the factors that prompt CEE unions to invest their relatively scarce resources in EU-level activism. Equally little is known about the mechanisms conditioning the selection of allies and the specific forms of their supranational engagement.

In a bid to address this gap, we analyze two EU-level initiatives undertaken by unions from Poland, the largest and most populous new EU Member State: lobbying against the EU Emission Trading Scheme (ETS) Directive and opposition to the draft EU Services Directive. These two cases featured particularly high levels of union mobilization, but involved different activities and patterns of cross-border coalitions. Focusing on the activities of Solidarność and OPZZ (Poland's biggest union confederations), as well as of their member organizations operating in the construction and energy sectors, we investigate what made the unions 'go European' and account for the observed divergence in regard to their selection of allies and strategies. Juxtaposing empirical evidence with available accounts of transnational labour activism, we argue that the scope and form of the organizations' EU-level engagement, as well as the type of coalitions they chose to join, primarily reflected their members' interests. These interests, in turn, were shaped by economic trends and regulatory changes in the two markets in question, in such a way that unions prioritized job protection in the case of the energy sector and the improvement of working conditions in the domain of services. All in all, the paper points to the relevance of interest-based accounts of supranational union activism, but it also demonstrates the interrelationship between labour interests, structural conditions and the role of EU-level networking.

The study is based on primary sources including press releases, EU documents, media publications and documents issued by national and EU-level union organizations, as well as on fourteen semi-structured interviews with union activists and policy experts involved in the elaboration of union strategies in the service market and energy fields.

The paper first reviews the literature on cross-border union activism. The empirical sections present recent regulatory developments in EU energy and service markets and describe Polish unions' initiatives in relation to regulatory proposals in these fields. The discussion section accounts for the observed mobilization patterns, while the last section outlines more recent union activities in the two sectors. Brief conclusions follow.

\section{Transnational Co-operation among Unions}

The cross-border co-operation and collective action of labour have been analyzed from a variety of perspectives. Socialization accounts, for instance, point to the integrating role of supranational activism. As argued by Gajewska (2009) and Greer and Hauptmeier (2012), repeated interactions among actors and interest groups from different countries 
may lead to the internationalization of common values and even to the creation of a common identity. Marginson et al. (2004) confirm that transnational union representation was the most influential in companies that featured intense union-liaising. Prior contacts similarly proved decisive for cross-border collective action in Erne's (2008) account of employee reactions to their companies' transnational merger plans. In some cases, multiple identities may co-exist as long as stable cross-border networks for exchange and communication are put in place (Meardi, 2012), and demands are framed in a manner that appeals to all actors involved (Leiren and Parks, 2014).

While socialization arguments emphasize the importance of sustained interactions, they fall short of explaining why unions get together in the first place. By claiming that labour representatives co-operate because they know and trust each other, they seem to suggest that co-operation emerges as a result of earlier co-operation; but this keeps us in the dark about the 'prime mover' behind actors' actions. Moreover, the socialization logic cannot account for the differing degrees of co-operation staged by actors with similar socialization experiences and for the specific patterns of the alliances they forge.

Another stream of literature highlights the role of structural factors in the emergence of labour transnationalism. According to Bieler (2005) and Larsson (2015), unions are more likely to act beyond state boundaries when the sectors in which they operate are organized on a transnational scale. This is because workers in transnationalized industries, unlike their counterparts from the public sector, are exposed to cross-border competitive pressures and have limited opportunities to address their concerns within national arenas. Their cross-border co-operation might be further enhanced by the existence of a joint managerial unit integrating all regional operations, which would serve as a union bargaining partner (Arrowsmith and Marginson, 2006; Marginson et al., 2004). The creation of transnational employee representation bodies such as European or World Works Councils can similarly help consolidate a unified labour front by providing an institutional framework for their cross-border exchanges (Anner et al., 2006). At some multinational companies, worker representatives work together towards the conclusion of International and/or European Framework Agreements on topics ranging from core social standards to corporate restructuring plans (Marginson, 2016). Global and European trade union federations often get involved in co-ordinating such joint initiatives and help gain publicity for transnational protest actions (Dufour-Poirier and Hennebert, 2013; Rüb and Platzer, 2015).

Transnational action is indeed largely the domain of actors affected by internationalization processes. However, it seems that, taken alone, structural explanations cannot account for the emergence of cross-border labour co-operation. If it were solely structural interdependence that brings about joint union activism, we would expect to witness a proliferation of co-operative initiatives, proportional to the speed at which companies are internationalizing. The somewhat slower pace at which the former processes are taking place indicates, on the contrary, that additional factors need to be present for cross-border union co-operation to emerge. Similar limitations apply to EU-level union mobilization. Structural theories predict that EU economic integration will give labour an incentive to become involved in EU-level action, but they fail to explain why unions in some sectors are more active than those in others.

In line with the third group of labour transnationalism accounts, unions, just like other socioeconomic interest groups, defend first and foremost the economic interests of their 
members; they thus become involved in transnational activism insofar as it helps them address their constituencies' concerns (Logue, 1980). In line with this interpretation, Fetzer (2008) examines joint initiatives staged by unions at General Motors and shows that, by staging transnational actions, representatives of individual plants served the interests of the local workforces. Interest-driven cross-border activism is assessed against strategic alternatives available to labour at the national level, which makes unions that are more deeply integrated in national decision-making systems less prone to transnational mobilization (Bieler, 2014). Even short-term 'windows of opportunity' for national-level interest representation might induce a change in union strategy: as shown by Bernaciak (2013), during the recent economic crisis General Motors workers withdrew from transnational co-operation and capitalized on their governments' increased willingness to intervene in company affairs.

Interest-based explanations seem more apt than the socialization and structural approaches to account for the form and scope of unions' transnational activities. Even so, they are problematic insofar as they treat actors' preferences as fixed and somewhat pre-defined, and therefore do not address the problem of interest formation. However, as argued by Fligstein (2001), in order to understand how actors will use the existing institutions to represent their interests and predict what alliances will be formed, one should analyze the organization of the particular markets in which they operate. Moreover, it is at times of creation or transformation of markets that actors become particularly aware of their interests and decide to articulate them. Following this line of reasoning, we hypothesize that the Europeanization of markets, that is their economic integration and regulatory harmonization, is likely to trigger heightened union involvement at the European level. However, depending on the character of changes in individual market segments, unions will pursue different agendas and forge different alliances at national and EU levels. In the next section, we analyze two such integrating EU markets: emission allowances and services.

\section{EU Market-making in the ETS and Service Sectors}

This section outlines recent developments in the areas of EU energy and climate policy and cross-border service provision. It shows that the two markets have become more deeply integrated, and examines how this has impacted on their growth prospects and employment conditions.

\section{The Reform of the EU Emission Trading Scheme}

Europe's concern with climate change began with the European Communities' declaration of carbon dioxide emission cuts and the debate about a common carbon tax in the early 1990s. Since the latter was rejected by some of its members in the 1990s, the EU had to look for an alternative policy instrument to comply with the emission reduction goals declared in the Kyoto Protocol. In 2003, it accordingly issued a Directive establishing the EU Emission Trading Scheme — the largest emission market in the world, covering over 11,000 industrial installations. Each installation, which stands for every $\mathrm{CO}_{2^{-}}$ emitting unit in companies involved in power and heat generation or energy-intensive industry sectors, receives permits to pollute, also known as European Allowances. 
The main challenge for every carbon market, including the European one, is to allocate emission allowances in a way that creates demand for them and makes their price high enough to persuade companies to invest in low-carbon technologies. In the first two phases of ETS (2005-07 and 2008-12), emission allowances were distributed by EU Member States' governments and allocated free of charge. In that period, companies tended to report emissions higher than was actually the case, bringing about a great surplus of allowances in the coming years (Pearson, 2010). This in turn pushed down their price, and the impact of ETS on the transition to low-carbon production in Europe proved minimal (Laing et al., 2013). At the same time, ETS helped power sector companies make considerable profits by letting them pass the market cost of emission allowances (obtained for free from the government) on to the electricity price (Pahle et al., 2011). These problems made the Commission substantially revise the allocation scheme. In January 2008, it proposed a Directive that put forward a common EU-level emission reduction target and an EU-wide allocation procedure, according to which the quantity of allowances placed on the market would decrease in linear fashion by a yearly factor of 1.74 per cent. Another important change was the rule of full auctions for electricity producers. Given that emission reduction targets comparable to those in the EU were still absent in other regions, however, the Commission proposed a gradual transition for installations in sectors exposed to global competition from 80 per cent of free allowances in 2013 to full auctions in 2020. Transnational allocation of emissions would be based on benchmarks that 'should take account of the most greenhouse gas and energy efficient techniques [and] production processes' (EC, 2008, p. 16). The Commission estimated that at least two-thirds of the total quantity of allowances would be auctioned, and that 90 per cent of the auctioned ones would be distributed according to the relative share of 2005 emissions. For reasons of fairness and solidarity, 10 per cent of the auctioned allowances would be redistributed from the richest EU countries to those with the lowest GDP per capita and highest growth prospects.

The 2008 ETS reform marked a breakthrough in EU climate policy. Until then, climate change had been mainly the concern of western European countries, forced to devise strategies to comply with the Kyoto targets. CEE states downsized their heavy industries in the early 1990s as part of the systemic transition, reducing their emissions significantly below the $\mathrm{CO}_{2}$ targets that they declared in the Kyoto Protocol. However, the 2008 reform - in particular, the obligatory purchase of allowances for the electricity production sector and the emission reduction baseline set in the years after the transition-related reforms - represented a challenge to CEE economies with powergeneration systems based on fossil fuels. In Poland, representatives of energy and mining industries, along with trade union organizations, realized that the Commission's proposal might have negative implications for their sectors and accordingly mobilized against the draft regulations.

\section{EU Service Markets: Towards Horizontal Liberalization}

The principles of the freedom to provide services (applying to companies temporarily involved in cross-border activity) and the freedom of establishment (referring to those permanently based on the territory of an EU Member State) featured in the 1957 Treaty establishing the European Economic Community. In the following decades, 
however, progress towards an integrated European service market was rather sluggish. This made the European Court of Justice (ECJ) take the lead in defining the concept of services, specifying the regulatory competences of both sending and host EU Member States and providing a catalogue of exceptions from the two freedoms (Hatzopoulos, 2008).

As part of the freedom to provide services, companies have the right to temporarily post their personnel to carry out work abroad. According to EU law, if such a posting lasts up to 24 months, posted workers' pension and social security contributions are paid in his/her country of origin. With regard to their wages and working conditions, however, the applicable legal regime long remained unclear. Here again, EU Member States initially relied on ECJ jurisprudence; the Court's Seco (1982) and Rush Portuguesa (1990) rulings confirmed that EU countries had the right to extend certain employment regulations to workers posted on their territory. Due to disagreements over the catalogue of extendable standards between the sending and host states of posted workers, located respectively in the EU's southern and north-western parts, joint EU regulations were long in coming. The so-called Posted Workers Directive (PWD) was adopted only in 1996, once national rules concerning posting had been put in place. The act provided a non-exhaustive catalogue of core host-country regulations that could be applied to posted workers (Eichhorst, 1998).

In the 1980s and 1990s, the EU adopted a selective approach to service market liberalization by issuing directives applicable to specific sectors. This 'patchwork' strategy (Lejour, 2008, p. 115) facilitated cross-border service flows in certain market areas, while in others technical and administrative barriers persisted. To remedy the situation, in December 2000 the Commission launched the Internal Market Strategy for Services that aimed to make the provision of services on a cross-border scale as easy as within a single country. The first step towards this goal was the 2002 Report on the State of the Internal Market in Services, which contained an inventory of obstacles that were emerging at different stages of service provision in the EU. In the second phase of the Strategy, in March 2004, the Commission issued a draft version of the Directive on Services in the Internal Market, also referred to as the Bolkestein Directive (after Frits Bolkestein, the then EU Commissioner for Internal Market and Services). The act aimed to remove the barriers identified in the 2002 Report through the application of the so-called 'country of origin principle (COP)', which made service providers subject exclusively to the laws of the EU Member State in which they were established.

The country-of-origin logic had featured as the 'Internal Market clause' in earlier EU acts targeting sub-fields of service markets (Hatzopoulos, 2008), but the draft Services Directive followed a horizontal approach and applied this logic 'to all economic activities involving services' (EC, 2004, p. 8). On the other hand, while COP remained the general rule, the act also provided for derogations from the principle. Nor was COP to apply to matters covered by the PWD; in the latter domain, host EU Member States were allowed to undertake controls 'to ensure compliance with the employment and working conditions applicable under [the PWD]' (EC, 2004, p. 36). Certain measures, such as authorization by host state authorities or the requirement to keep employment documents in the territory of the host state, were nevertheless forbidden. As we will show in the following section, $\mathrm{COP}$ and the accompanying restrictions on host-country controlling rights met with strong criticism from labour organizations. 


\section{Trade Unions' Reactions to EU-level Regulatory Developments}

This section documents Polish trade unions' reactions to EU-level regulatory changes in the fields of energy policy and cross-border service provision. It also presents the arguments that were put forward to justify their stances on these two issues.

\section{Lobbying Against the Draft ETS Directive}

In March 2008 the European Trade Union Confederation (ETUC) supported the Commission's draft Directives on the Climate Change and Energy Package, with a positive vote from Solidarność's confederal representatives. In June 2008, however, a negative reaction to the ETUC's position came from Solidarność's Mining and Energy Section (SGiE), which asserted that the price of coal-generated electricity in Poland would rise as a result of the ETS reform. This, in turn, would increase production costs for Polish industry and threaten jobs in the mining, energy and industry sectors (Interview SGiE, 2008). In July 2008, the Tripartite Commission for Mine Workers' Social Security, consisting of representatives of coal sector unions, employers and the Polish government, similarly argued that the Commission's proposal would lower the coal industry's competitiveness in Poland and other EU Member States (Tripartite Commission, 2008).

In mid-2008, SGiE asked the ETUC to revise its position on the Package and the ETS system, suggesting that the ETUC urge the European Commission to take into account differences between EU Member States' economies in terms of their GDP levels and energy mixes, such as their dependence on a single fossil fuel. The ETUC refused to comply with this request and as result, $\mathrm{SGiE}$ set out to look for allies within the European Mine, Chemical and Energy Workers Federation (EMCEF) that also disapproved of the ETUC's position on the Package because of the potentially high costs of the amended ETS to its members, in particular in Germany. In October 2008, SGiE, in co-operation with the Miners' Trade Union (ZZG) affiliated at OPZZ and EMCEF Coordination Council, organized a meeting in Katowice, Poland. It was attended by the EMCEF Secretary, the ETUC Confederal Secretary and the presidents of other Polish mining and chemical unions. The meeting resulted in a declaration stating that the Package would lead to a rapid increase in electricity and heating costs across Europe. Its implementation would trigger closures of European coal-based power plants, and thus many countries would have to import electricity from outside the EU. Manufacturing industries would also face mass import threats given that from 2012 they were to participate in auctions for $\mathrm{CO}_{2}$ emission allowances. All in all, the EU could lose around 1 million jobs (EMCEF, 2008a). The SGiE leader additionally commented on the implications of the Commission proposals for investments:

... [E]lectricity prices will surely rise. Clients will have to pay for emission reductions and nobody will come to invest in Poland because it will be more expensive to invest here. (...) The industry might move out from Europe overnight. (...) And this will cause unemployment in the EU (Interview SGiE, 2008).

In November 2008, SGiE organized yet another conference in Katowice with an aim to mobilize a common front for an international protest to be held at the beginning of December 2008, before the European Parliament's final vote on the Package. Over 20 union delegates from different countries, including Poland, Bulgaria, Romania, 
Germany and Italy, as well as representatives of the International Trade Union Confederation (ITUC-TUAC), ETUC and EMCEF, attended the meeting. Representatives of a Polish electricity industry lobbying group, the Polish Ministry of Environment and the World Wildlife Fund (WWF) also participated. Despite tensions between the Polish unions and EMCEF on one side, and ETUC, ITUC-TUAC and WWF on the other, the meeting ended with a common statement:

The Climate Change and Energy Package should be introduced. However, introducing the package in its current state may result in the closing down of hundreds of thousands of workplaces in the EU and at the same time the $\mathrm{CO}_{2}$ emitting industry and investments connected to it might move outside of the EU. These possible consequences will shatter the goals of the (...) Package (EMCEF, 2008b).

According to an EMCEF expert, the Katowice conference strengthened solidarity between SGiE and EMCEF:

(...) [A] nice thing about the meeting (...) was that we made it clear to the SGiE leader and his 'gang' that he had to make a coalition with us and the industries. We had the same interest, a very clear common interest, and they could see it clearly in joint positions we adopted (Interview EMCEF, 2009).

In Katowice, Polish unions felt they belonged to a big family with their European colleagues (Interview SGiE, 2009). The members of this family were carefully selected, however: they were from EMCEF and not directly from the ETUC. The joint protest eventually did not take place because it became clear that the final decision would be taken at the EU summit attended by heads of states. And even though this alliance did not influence the ETUC's position on the Package, Polish unions had succeeded in drawing more attention to their claims and forced the ETUC to engage in a debate. During final negotiations of the Package, Poland managed to get an opt-out from full auctions for electricity producers and secure a larger share of emission allowances for companies operating in its territory. These gains followed the negotiation lines of the Polish labour organizations and were seen by them as a partial victory.

\section{Mobilization Against the Draft Services Directive}

The EU's horizontal approach to service market liberalization was assessed negatively by the ETUC. The organization argued that the Commission's proposal was not preceded by an appropriate impact assessment and relied on too broad a definition of market barriers, in which all regulations constituted obstacles to economic activity and should thus be discarded (Kowalsky, 2006; Interview ETUC1, 2015). Moreover, it feared that even though matters covered in the PWD were formally excluded from the Directive's scope, restrictions of states' controlling rights would hinder the effective enforcement of the existing employment standards and encourage rule circumvention.

Solidarność and OPZZ shared the ETUC's criticism of the proposed act. However, their position was not guided solely by feelings of solidarity towards western European workers; it also reflected unions' concerns over the impact of the EU service market liberalization on the Polish legal system and labour market standards.

In the post-transitional Poland, collective bargaining has taken place predominantly at the company level and covered a small share of the workforce (15.7 per cent in 2007; 
Visser, 2015). As a result, statutory rules, in particular the country's Labour Code, have played a crucial role in setting the applicable employment standards. According to the Poles, changes stipulated by the draft Service Directive would pose a threefold threat to this legal order. First, in the areas and sectors governed by COP, they would trigger deregulatory processes and result in cut-throat rivalry between EU service providers. In this competitive race, cost advantages for Polish businesses and workers would be short-lived, given that social standards in prospective EU Member States were even lower than in Poland (see Bankier, 2006). Secondly, similarly to the ETUC, Polish unions feared that the far-reaching restrictions on EU Member States' supervisory rights would hinder effective law enforcement and lead to the intensification of abuses. The unions accordingly claimed that it would be ill-advised to relinquish national controlling instruments given that the Directive 'did not provide anything in exchange at the EU level' (Interview ETUC2, 2007). Thirdly, the Poles were wary of the legal uncertainty brought about by COP and demanded that service providers abide by host-country rules:

A Belgian driver, with a Belgian driving licence, is allowed to drive in Poland, but he/she must obey Polish traffic regulations. Or if you purchase a Mercedes in Germany, this doesn't imply that you can drive at $160 \mathrm{~km} / \mathrm{h}$ on a motorway in Poland, where the speed limit is $130 \mathrm{~km} / \mathrm{h}$. It would be really stupid to allow that! Why should this apply to other areas? (Interview Solidarność1, 2007).

Beyond protecting the legal status quo in the social sphere, Polish unions advocated the gradual improvement of working conditions in Poland and their approximation towards those in older EU Member States. They were aware, however, that this long-term goal of 'upward rather than downward convergence' (OPZZ, 2006) could materialize only if the higher western European standards were preserved. Regulatory competition spurred by COP, as well as the weakening of western European collective bargaining systems resulting from the limitation of host-country controlling rights, could destroy the western social ideal to which the Poles were aspiring. This, in turn, would mean that there were 'no chances for the improvement of [Polish] workers' material conditions' (Interview Budowlani, 2006).

Solidarność and OPZZ sought to win over the wider public in national debates on the draft Directive. This was a difficult task given that both the government and the country's mainstream media encouraged Polish companies to utilize their cost advantages and accused the unions of 'an ill-intentioned solidarity with [western] trade unions' (Gazeta Wyborcza, 2006). Despite the critique, the two confederations co-operated with leftist NGOs and smaller labour organizations, issuing a call for protests against the Directive and gathering signatures under a Europe-wide petition. They also made their stance clear at EU level: during a Brussels conference in December 2005, the Solidarność president condemned COP and warned against the myopia of cost competitiveness (Euractiv, 2005).

Solidarność and OPZZ utilized their own access channels to EU officials to make their voice heard during EU-level debates on the draft act. In early February 2006, shortly before the European Parliament's vote on the revised version of the Directive, the OPZZ president met with the chairman of the Polish section of the Party of European Socialists (PES). Both organizations also held additional meetings with Polish MEPs from PES and the Alliance of Liberals and Democrats for Europe (ALDE), urging the latter to stop the 
across-the-board liberalization of EU service markets. Finally, the Poles participated in demonstrations against the draft Directive organized by the ETUC. The March 2005 protest in Brussels coincided with the EU Competitiveness Council's discussion on the draft Directive. The February 2006 Strasbourg demonstration, which preceded the European Parliament's vote on amendments, was attended by 400 Polish union members representing the two confederations and their sectoral federations. The pan-European union mobilization led to the removal of the contested COP from the Directive and gave national governments the right to impose stricter regulations to protect public interest.

\section{EU-level Union Activism in Defence of Members' Interests}

Why did the unions 'go European' and what conditioned their choice of allies at the supranational level? In light of the evidence from the two case studies, it seems that none of the accounts of labour transnationalism outlined in the literature review section should be refuted, even though the importance of individual variables differed. Structural changes - in particular, the creation of EU-wide markets for emission allowances and for services - clearly played an important role in stimulating union involvement at EU level. In both sectors, supranational regulations were expected to influence domestic institutions and business operations, which provided a powerful 'pull' for the Polish unions to invest their resources in EU-level activities. Once 'in Brussels', the organizations did not operate in a vacuum; earlier socialization experiences gained through bilateral co-operation and membership of EU-level federations helped them liaise with their counterparts from other countries. The actual scope of the unions' EU-level actions, however, as well as their choices as to which coalitions they joined, were primarily a function of their constituencies' interests and union goals in particular market segments (Figure 1).

The issue of members' interests and union goals has been analyzed in the economic and industrial relations literature. Dunlop's (1944) contribution to the economic theory of trade unions assumes that labour organizations maximize their members' wages. Bargaining models, in turn, define union objective function not only in terms of wage

Figure 1: The Relation between the Main Explanatory Variable and Other Factors Stimulating EU-level Union Activism.

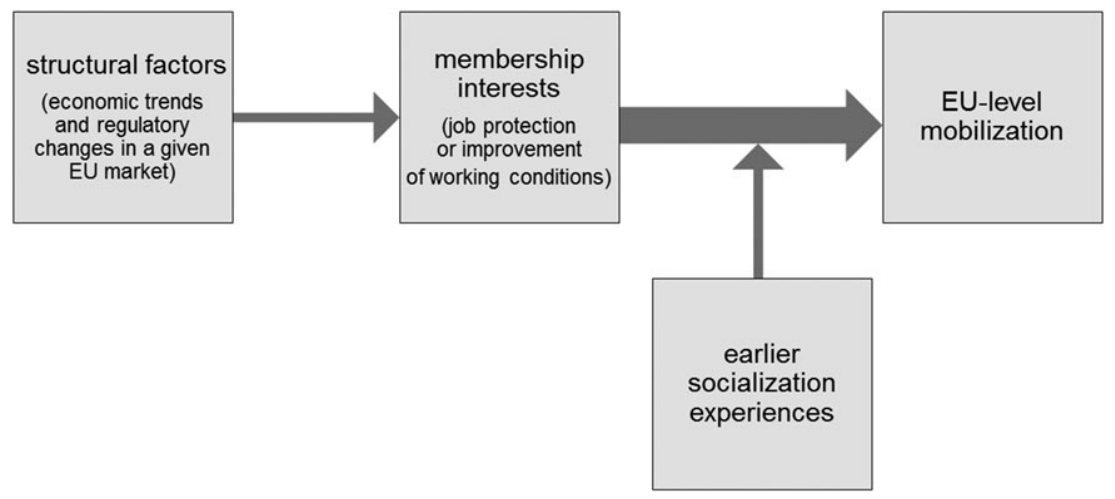


demands but also claims for job protection, which are constrained by employers' labour demand function (Pencavel, 1984). They also refer to a possible trade-off between wage increases and employment protection, which implies that, in practice, these two objectives might not be pursued simultaneously - or at least not to an equal extent. This assertion is confirmed by empirical studies conducted in the US context, which show that the relative weight of the two goals in the overall set of union activities varies significantly across localities and reflects local labour market conditions (Dertouzos and Pencavel, 1980). In Europe, the different emphases placed by unions on wageand employment-related issues have not been a subject of separate inquiry, even though the two notions clearly feature on union agendas to differing extents. To give just one example, German unions are known for their readiness to get involved in so-called concession bargaining and to reduce wages in exchange for job guarantees (Jürgens and Krzywdzinski, 2006). Scandinavian unions, by contrast, do not seek to save employment 'at all costs'; they are more inclined to accept layoffs rather than pay cuts if the former increase the company's efficiency (Knudsen, 2005).

The literature explains the contrast between the German and Scandinavian approaches by pointing to cross-country differences in bargaining structures, labour market institutions and union traditions (Pulignano, 2006). In our paper, we control for industrial relations and labour market variables by selecting trade unions from a single-country setting. This allows us to relate membership interests and union goals to market-specific factors, in particular to economic trends and regulatory developments in specific market segments. As we show below, these were different in each of the two examined cases.

Due to state involvement, Polish enterprises in mining and coal-based electricity generation enjoyed a dominant position in the Polish electricity market for a long time; in the mid-2000s, mining alone employed over 120,000 people (Bluszcz, 2014). When the price of coal was still relatively high, production from renewable energy sources was growing but still relatively low, and the shale gas extraction was still to come, coal was seen by consecutive Polish governments as 'the fuel' that could supply cheap, domestic electricity. The Commission's 2008 proposal defied this vision as it expected energy markets in all EU Member States to undergo a transition to low-carbon electricity production. Against this background, Polish unions viewed the new EU emission allocation regime as a threat to the very existence of the mining and coal-based electricity sectors in Poland. They did not delve into an in-depth analysis of the extent to which working conditions would be affected by the upcoming change of regulations as they were first and foremost concerned with the potential job losses implicated by the ETS reform.

Poland's service sector experienced unprecedented growth in the decade preceding the Service Directive dispute; the country's service providers were also quick in seizing new business opportunities that had been opened up by EU enlargement in 2004 and expanding abroad (Foreign Ministry, 2014). The strong performance and substantial development potential of the service sector encouraged Polish trade unions operating within it to demand better conditions for their members. Since the unfettered liberalization of intra-EU service flows could undermine the norms of old EU Member States, which were used by the Polish unions as a frame of reference for their own claims, Polish labour organizations also had a stake in defending western European wage-setting systems. They therefore demanded higher wages for Polish employees working in the west or temporarily sent there within the framework of free services provision. An additional reason for 
prioritizing the improvement of working conditions over employment issues was that potential job cuts, linked to the loss of cost advantage for posting companies, would not affect union members but rather non-unionized migrants and posted workers employed predominantly in market segments characterized by a weak union presence.

\section{Crisis and Cross-border Labour Mobilization}

The recent economic downturn was a tough test for cross-border union activism. Individual EU Member States were affected by the downturn to differing degrees; consequently, a 'shared sense' of the crisis and a commonality of interests among European workers the foundations of a unified anti-austerity front - were missing (Dribbusch, 2015, p. 175). As further argued by Erne (2015), certain elements of the new European economic governance system could paradoxically strengthen the national orientation of social actors. For instance, the new mechanism of debt control that is based on recommendations directed to individual EU Member States pits national economies against each other and might trigger a new wave of 'competitive corporatism' aimed at securing individual countries' compliance with the Commission's benchmarks.

Not all policy areas are equally prone to re-nationalization however. In the fields where the EU sets clear and uniform rules for all EU Member States, labour organizations are unlikely to abandon transnational activism, given their limited capacity to shape the applicable regulations and/or to cushion their impact on their members through national-level solutions. In the two sectors analyzed in this article, European regulations have this uniform, horizontal character, something that has had implications for union actions. Even though the scale and intensity of their mobilization against the ETS scheme and draft Services Directive have so far been unprecedented, Polish labour organizations have continued their EU-level involvement and upheld their earlier positions in relation to recent regulatory developments in the two markets.

In the field of energy, EU climate policies and more recent projects towards creating an energy union, in combination with low coal prices, continued to be viewed by Polish labour organizations as direct threats to the existence of Polish mining, coal-based and electricity-generating sectors. In 2012, the unions tried to use the European Citizens' Initiative to block the EU Climate Change Package but they failed to collect the required number of signatures (Adamczyk and Surdykowska, forthcoming). In 2013, representatives of the Polish mining and energy unions still considered EU climate policy as the most problematic policy area that had to be addressed via EU-level action; they also maintained that unions should defend the sectors' interests beyond state boundaries (Interview SGiE, 2013; Interview ZZG1, 2013; Interview ZZG2, 2013). Transnational co-operation between Polish mining and energy unions and their counterparts from other countries affiliated to EMCEF's successor IndustriAll Europe was sustained during the downturn. In 2014, this pro-carbon coalition made IndustriAll adopt a position that declared each country had the right to determine its own energy mix (IndustriAll, 2014). In the same year, the three Polish union confederations - Solidarność, OPZZ and FZZ — voted against the ETUC resolution supporting the second Climate Change Package (Adamczyk and Surdykowska, forthcoming). Besides direct EU-level actions, the organizations supported the Polish government's attempts to question the legitimacy of the EU carbon emission trade. In January 2016, the cabinet submitted a claim against 
the ETS to the Court of Justice of the EU. In particular, they objected to shifting the starting date for the operation of the ETS reform to 2019, which allegedly provoked economic uncertainty (Euractiv, 2016).

With cross-border service provision on the rise and liberalization high on the agenda of EU institutions, Polish labour organizations upheld their critical view on across-the-board deregulatory initiatives. They accordingly disapproved of the ECJ's 2007 Laval and Viking judgements, which put EU economic freedoms before social protection and made it more difficult for unions to defend national labour market regulations. By contrast, they welcomed additional safeguards introduced by the 2014 PWD Enforcement Directive, arguing that these were necessary to prevent abuses in relation to the posting of employees (Interview Solidarność2, 2016). The unions also became involved in disclosing cases of 'rule bending' related to cross-border movement of workers and service provision. They intervened in individual cases of worker exploitation, participated in EU-wide anti-social dumping protests and liaised with unions from other countries operating in abuse-prone sectors (Atema, 2015; Interview Solidarność3, 2007). In March 2016, the Poles backed the Commission's proposal to revise the PWD, which stipulated that posted workers should not be paid in line with the minimum wage of the host country but instead receive remuneration equal to that of the local workforce. Justifying their stance, the unions employed arguments similar to those used against the draft Services Directive, calling for the clarification of posting regulations, the preservation of western European collective bargaining systems and the 'upward convergence' of Polish wages and working conditions towards western standards (Interview Solidarność2, 2016; Interview Solidarność4, 2016; Interview OPZZ, 2016). Even before the official presentation of the revision proposal, the OPZZ president sent a letter to the EU Commissioner for Employment, Social Affairs, Skills and Labour Mobility declaring his organization's support for the equal wage initiative and 'social integration in the EU' (OPZZ, 2015). Polish unions also delegated their representatives to an ETUC Task Force on posting, which was created in reaction to the Commission's proposal, and expressed a willingness to participate in future EU-level actions related to PWD revision.

\section{Conclusions}

Contrary to the expectations derived from the CEE labour weakness thesis, Polish unions did become involved in EU-level actions. Both initiatives examined in this paper - lobbying against the carbon emission quotas and opposing the unfettered liberalization of cross-border service flows - were undertaken in the context of the integration of European energy and service markets and guided by the interests of union constituencies in the two sectors.

It is noteworthy that unions from other CEE countries similarly joined the two coalitions and participated in EU-level actions, which suggests that the mechanism identified in our paper is valid beyond the Polish setting. If important structural and regulatory changes are decided upon beyond state boundaries, even organizations with limited resources will 'go transnational' and lobby for solutions that are favourable to their members. At the same time, the relative weakness of these unions is likely to make them highly selective in their choices of potential allies; they will accordingly cherry-pick platforms and agendas offering the highest gains to their constituencies. The case of 
unions in the mining and energy sector illustrates this logic particularly well. The Poles perceived themselves as a part of the European labour movement. Through co-operation with European umbrella organizations, they gained a stronger voice in their relations with both domestic and EU-level actors, and they also developed a closer sense of solidarity with the ETUC (Lis, 2015). However, as pointed out by Solidarność representatives themselves (Adamczyk and Surdykowska, forthcoming), this attachment was not unconditional. In defence of their constituencies' interests, Polish energy unions were able to act autonomously from the ETUC and ally with their like-minded counterparts from European industrial federations and coal-producing countries. Importantly, the financial crisis did not change their perception of EU climate policies as a major threat to the Polish mining and energy sectors and thus did not divert Polish union activities away from the EU arena; nor did the service sector unions ignore the recent Commission proposals for changes to the regulation of intra-EU employee posting. This testifies to the continued relevance of EU horizontal policies and regulations for national labour organizations. At a more general level, it demonstrates the enduring need for interest groups to design effective strategies to tackle the opportunities and challenges engendered in European market-making processes.

Correspondence:

Magdalena Bernaciak

European Trade Union Institute (ETUI)

Boulevard du Roi Albert II, 5 box 4

1210 Brussels

Belgium

email: mbernaciak@etui.org

\section{References}

Adamczyk, S. and Surdykowska, B. (Forthcoming) 'Polskie związki zawodowe a reprezentowanie interesów pracowniczych na poziomie UE' ['Polish Trade Unions and Employee Interest Representation at the EU Level']. In Krzysztof Jasiecki, K. and Kurczewska, U. (eds) Reprezentacja narodowych interesów i lobbing gospodarczy w Unii Europejskiej [National Interest Representation and Economic Lobbying in the EU'].

Anner, M., Greer, I., Hauptmeier, M., Lillie, N. and Winchester, N. (2006) 'The Industrial Determinants of Transnational Solidarity: Global Interunion Politics in Three Sectors'. European Journal of Industrial Relations, Vol. 12, No. 1, pp. 7-27.

Arrowsmith, J. and Marginson, P. (2006) 'European Cross-Border Dimension to Collective Bargaining in Multinational Companies'. European Journal of Industrial Relations, Vol. 12, No. 3, pp. 245-266.

Atema, E. (2015) Presentation at the Midterm Conference of the ETUC Project on Letter-box Companies Amsterdam, 17 November.

Avdagić, S. (2004) 'Loyalty and Power in Union Party Alliances. Labor Politics in Postcommunism'. MPIfG Discussion Paper, No. 04/7.

Bankier (2006) 'Nasi Związkowcy Boją się Rumuńskich Hydraulików' ['Our Trade Unions Are Afraid of Romanian Plumbers']. Press article. Available online at: http://www.bankier.pl/ firma/ue/article.html?article_id=1401624. Last accessed: 5 June 2008.

Bernaciak, M. (2013) 'Labour Solidarity in Crisis? Lessons from General Motors'. Industrial Relations Journal, Vol. 44, No. 2, pp. 139-153. 
Beyer, J. (2002) 'Gaining and Seeking Access: The European Adaptation of Domestic Interest Associations'. European Journal of Political Research, Vol. 41, No. 5, pp. 585-612.

Bieler, A. (2005) 'European Integration and the Transnational Restructuring of Social Relations: the Emergence of Labour as a Regional Actor?' JCMS, Vol. 43, No. 3, pp. 461-484.

Bieler, A. (2014) 'Transnational Labour Solidarity in (the) Crisis'. Global Labour Journal, Vol. 4, No. 2, p. 114-133.Available online at: https://escarpmentpress.org/globallabour/article/view/ 1154., Last accessed: 29 April 2016.

Bluszcz, A. (2014) 'Proces przemian struktury zatrudnienia w górnictwie węgla kamiennego' ['The Change of the Employment Structure in the Coal Mining Sector']. Studia Ekonomiczne, Vol. 196, pp. 103-113.

Bohle, D. and Greskovits, B. (2010) 'Slovakia and Hungary: Successful and Failed Euro Entry without Social Pacts'. In Pochet, P. and Natali, D. (eds) After the Euro and Enlargement: Social Pacts in the EU (Brussels: ETUI), 345-369.

Dertouzos, J.N. and Pencavel, J.H. (1980) 'Wage and Employment Determination Under Trade Unionism: The International Typographical Union'. Journal of Political Economy, Vol. 89, No. 6, pp. 1162-1181.

Dribbusch, H. (2015) 'Where is the European General Strike? Understanding the Challenges of Trans-European Trade Union Action Against Austerity'. Transfer, Vol. 21, No. 2, pp. 171-185.

Dunlop, J.T. (1944) Wage Determination Under Trade Unions (New York: Macmillan).

Dufour-Poirier, M. and Hennebert, M.-A. (2013) 'The Transnationalization of Trade Union Action within Multinational Corporations: A Comparative Perspective'. Economic and Industrial Democracy, Vol. 36, No. 1, pp. 73-98.

EC (2004) 'Proposal for a Directive on Services in the Internal Market'. COM(2004)2 final 2004/ 0001 (COD). Brussels, 13 January 2004. Available online at: http://eur-lex.europa.eu/legal-content/EN/TXT/PDF/?uri=CELEX:52004PC0002\&from=EN. Last accessed: 2 February 2016.

EC (2008) 'Proposal for a Directive 2003/87/EC Amending Directive 2003/87/EC so as to Improve and Extend the Greenhouse Gas Emission Allowance Trading System of the Community'. COM(2008)16 final 2008/0013 (COD). Brussels, 23 January 2008. Available online at: http://eur-lex.europa.eu/LexUriServ/LexUriServ.do?uri=COM:2008:0016:FIN:en: PDF. Last accessed: 1 February 2016.

Eichhorst, W. (1998) 'European Social Policy between National and Supranational Regulation: Posted Workers in the Framework of Liberalized Services Provision'. MPIfG Working Paper, No. $98 / 6$.

EMCEF (2008a) 'Position of the Coordination Office of EMCEF-Poland about the Climate and Energy Package, October 2008'. Coordination Council EMCEF Poland, 7 October. Unpublished document.

EMCEF (2008b) 'Appeal to the European Commission to Launch Negotiations with the Social Partners about the Climate and Energy Package'. Coordination Office of EMCEF Poland, 13 November. Unpublished document.

Erne, R. (2008) European Unions. Labor's Quest for a Transnational Democracy (Ithaca and London: Cornell University Press).

Erne, R. (2015) 'A Supranational Regime that Nationalizes Social Conflict. Explaining European Trade Unions' Difficulties in Politicizing European Economic Governance'. Labour History, Vol. 56, No. 3, pp. 345-368.

Euractiv (2005) 'Services: Unions East and West Criticise Country of Origin Principle', 7 December. Available online at: http://www.euractiv.com/socialeurope/services-unions-east-westcriticise-country-origin-principle/article-150537. Last accessed: 15 January 2016.

Euractiv (2016) 'Polska pozywa UE ws. ETS' ['Poland Takes the EU to Court over the ETS'], 7 January. Available online at: http://www.euractiv.pl/energia-srodowisko/wywiad/polskapozywa-ue-ws-ets-007811. Last accessed: 7 July 2016. 
Fetzer, T. (2008) 'European Works Councils as Risk Communities: the Case of General Motors'. European Journal of Industrial Relations, Vol. 14, No. 3, pp. 289-308.

Fligstein, N. (2001) The Architecture of Markets: An Economic Sociology of Twenty-First-Century Capitalist Societies (Princeton, NJ and Oxford: Princeton University Press).

Foreign Ministry (2014) Poland's 10 Years in the European Union (Warsaw: Ministry of Foreign Affairs).

Gajewska, K. (2009) Transnational Labour Solidarity. Mechanisms of Commitment to Cooperation within the European Trade Union Movement (New York: Routledge).

Gazeta Wyborcza (2006) 'Związki Zawodowe Krzyczą: Hydraulik Musi Zostać!' ['Trade Unions Scream: the Plumber Needs to Stay!']. Press article. Available online at: http://www.archiwum. wyborcza.pl/Archiwum/1,0,4600992,20060316RP-DGW,Zwiazki_zawodowe_krzycza_hydraulik _musi_zostac,html. Last accessed: 16 October 2015.

Greer, I. and Hauptmeier, M. (2012) 'Identity Work: Sustaining Transnational Collective Action at General Motors Europe'. Industrial Relations, Vol. 51, No. 2, pp. 275-299.

Hatzopoulos, V. (2008) 'Legal Aspects of the Internal Market for Services'. In Pelkmans, J., Hanf, D. and Chang, M. (eds) The EU Internal Market in Comparative Perspective (Brussels: Peter Lang), 77-92.

IndustriAll (2014) '2030 Framework for Energy and Climate Policies - Towards European Climate and Energy Policy'. Brussels: IndustriAll European Trade Union. Available online at: http://www.industriall-europe.eu/committees/IP/PolPaper/PP2014-02-Energy-EN.pdf. Last accessed: 15 June 2016.

Jürgens, U. and Krzywdzinski, M. (2006) 'Globalisierungsdruck und BeschäftigungssicherungStandortsicherungsvereinbarungen in der deutschen Automobilindustrie zwischen 1993 und 2006' ['Globalization Pressure and Safeguarding Employment - Agreements to Prevent Plant Closures in the German Automotive Industry between 1993 and 2006']. WZB Discussion Paper, No. 2006-303.

Knudsen (2005) 'Scandinavian Scepticism: Danish and Swedish Trade Unionism in the European Context'. Paper presented at the workshop on Europeanisation and Organised Labour: An Unsolved Dilemma? University of Warwick, Coventry, 18--19 November.

Kowalsky, W. (2006) 'The Services Directive: the Legislative Process Clears the First Hurdle'. Transfer, Vol. 12, No. 2, pp. 231-249.

Laing, T., Sato, M., Grubb, M. and Comberti, C. (2013) 'Assessing the Effectiveness of the EU Emission Trading System'. Centre for Climate Change Economics and Policy Working Paper, No. 126.

Landgraf, C. and Pleines, H. (eds) (2015) Interest Representation and Europeanization of Trade Unions from EU Member States of the Eastern Enlargement (Stuttgart: ibidem-Verlag).

Larsson, B. (2015) 'Trade Union Channels for Influencing European Union Policies'. Nordic Journal of Working Life Studies, Vol. 5, No. 3, pp. 101-121.

Leiren, M.D. and Parks, L. (2014) 'When Trade Unions Succeed: Cases of Blocked Liberalisation in the Common Market'. European Journal of Political Research, Vol. 53, No. 3, pp. 465-479.

Lejour, A. (2008) 'Economic Aspects of the Internal Market for Services'. In Pelkmans, J., Hanf, D. and Chang, M. (eds) The EU Internal Market in Comparative Perspective (Brussels: Peter Lang), 115-138.

Lis, A. (2015) 'Different Faces of Europeanization. The Case of NSZZ Solidarność'. In Landgraf, C. and Pleines, H. (eds) Interest Representation and Europeanization of Trade Unions from EU Member States of the Eastern Enlargement (Stuttgart: ibidem-Verlag), 255-276.

Logue, J. (1980) Toward a Theory of Trade Union Internationalism (Gothenburg: University of Gothenburg Press). 
Marginson, P. (2016) 'Trade Unions and Multinational Companies: A Multi-level Challenge'. Warwick Papers in Industrial Relations, No. 103.

Marginson, P., Hall, M., Hoffmann, A. and Müller, T. (2004) 'The Impact of European Works Councils on Management Decision-Making in UK and US-based Multinationals: A Case Study Comparison'. British Journal of Industrial Relations, Vol. 42, No. 2, pp. 209-233.

Meardi, G. (2012) 'Union Immobility? Trade Unions and the Freedoms of movement in the Enlarged EU'. British Journal of Industrial Relations, Vol. 50, No. 1, pp. 99-120.

OPZZ (2006) 'Związkowcy w Strasbourgu za Europą Socjalną' [Trade Unions in Strasbourg in Favour of Social Europe']. Kronika Zwiazkowa, Vol. , No. 24, p. 1-2.

OPZZ (2015) Letter to Ms Marianne Thyssen. Warsaw, 15 October.

Pahle, M., Fan, L. and Schill, W.-P. (2011) How Emission Certificate Allocation Distorts Fossil Investments: The German Example (Berlin: Deutsches Institut für Wirtschaftsforschung).

Pearson, A. (2010) The Carbon Rich List: The Companies Profiting from the EU Emission Trading Scheme (London: Sandbag).

Pencavel, J. H. (1984) 'The Tradeoff between Wages and Employment in Trade Union Objectives'. NBER Working Paper, No. 870.

Pulignano, V. (2006) 'Sill "Regime Competition”? Trade Unions and Multinational Restructuring in Europe'. Relations Industrielles/Industrial Relations, Vol. 61, No. 4, pp. 615-635.

Rüb, S. and Platzer, H.-W. (2015) The Europeanization of Industrial Relations in the Service Sector (Brussels: Peter Lang).

Tripartite Commission (2008) 'Position Regarding a Proposal of the European Commission known as the Climate and Energy Package'. The Tripartite Commission for the Mining Workers' Social Security, Katowice, 30 July. Unpublished document.

Visser, J. (2015) ICTWSS database 5.0. Available online at: http://www.uva-aias.net/208. Last accessed: 9 May 2016.

\section{Interviews}

Budowlani 2006 - ZZ Budowlani official; Budapest, 4 April.

EMCEF 2009 - EMCEF official; Brussels, 24 June.

ETUC1 2015 - ETUC official; Brussels, 1 June.

ETUC2 2007 - former Solidarność activist and ETUC official; Brussels, 3 October.

OPZZ 2016 - Head of OPZZ International Office; phone interview, 10 May.

SGiE 2008 - SGiE official; Warsaw, 22 October.

SGiE 2009 - SGiE official; phone interview, 17 January.

SGiE 2013 - SGiE official; phone interview, 16 April.

Solidarność1 2007 - Head of Solidarność International Office; Gdańsk, 3 January.

Solidarność2 2016 - Expert at Solidarność Social Policy Department; phone interview, 9 May.

Solidarność3 2007 - Officer at Solidarność International Office. Gdańsk, 16 June.

Solidarność4 2016 - Expert at Solidarność Legal Department; phone interview, 23 May.

ZZG1 2013 - ZZG Vice-President 1; phone interview, 9 May.

ZZG2 2013 - ZZG Vice-President 2; phone interview, 23 May. 